\title{
Factors Related to the Incidence of Typhoid Fever in the Work Area Health Office of Jayawijaya Regency
}

\author{
Rahmad Suryawan Ura', \\ Yuly Peristiowati ${ }^{2}$ \\ ${ }^{1}$ Master of Public Health Study \\ Program \\ ${ }^{2}$ Institute of Health Sciences \\ STRADA Indonesia \\ Email: \\ rahmadsuryawan19@gmail.com
}

Received : October $4^{\text {nd }} 2021$

Accepted : October $15^{\text {rd }} 2021$

Published : November $27^{\text {th }} 2021$

\begin{abstract}
Typhoid fever is a disease that is prone to occur in Indonesia, because of the characteristics of the climate that is very prone to diseases related to the seasons. The purpose of this study is to analyze factors related to the incidence of typhoid fever in the Working Area of the Jayawijaya District Health Office.

The research design used is quantitative analytics method using quantitative data. The type of approach used is case control. The population is 74 patients with typhoid fever. The large sample taken as many as 37 respondents, with a large comparison of samples between the number of respondents in the case group is 37 respondents, and 37 respondents as a control group, so the total number of samples is 74 respondents. Sampling techniques used in this study is a simple random sampling technique.

Based on the results of the study, it is known that there is no relationship between age and the incidence of typhoid fever in the Working Area of the Jayawijaya District Health Office. Chisquare test result obtained p-Value Sig $(0.445)>\alpha(0.05)$. While it is known that there is a relationship between the level of knowledge, the level of education, hygiene of individual respondents with the incidence of typhoid fever in the Work Area of the Health Office of Jayawijaya Regency. Chi-square test results obtained $\mathrm{p}$ - value $(0.000)<\alpha(0.05)$ and environmental sanitation with the incidence of Typhoid Fever in the Work Area of the Jayawijaya District Health Office. Chi-square test result obtained p-value $(0.001)<\alpha(0.05)$.

Based on the results of the study is expected to increase kinship with patients as well as by providing health services visits to the patient's home.
\end{abstract}

Keywords: Factors, events, typhoid fever

Copyright @ 2021 IIK STRADA Indonesia All right reserved.

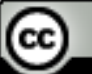

This is an open-acces article distributed under the terms of the Creative Commons Attribution-ShareAlike 4.0 International License.

\section{INTRODUCTION}

The exact number of cases of typhoid fever in the world is very difficult to determine because the disease is known to have symptoms with a very wide clinical spectrum. World Health Organization (WHO) data in 2003 estimated that there are approximately 17 million cases of typhoid 
fever worldwide with an incidence of 600,000 cases of death each year.4 Cases of typhoid fever in developing countries are reported as endemic diseases where $95 \%$ are outpatient cases so the actual incidence is $15-25$ times greater than hospital hospital reports.

Health problems are very complex problems, which are interrelated with other problems outside the health problem itself as well as to overcome public health problems not only seen in terms of their own health but must be in terms of the environment that affects the degree of health, one of the problems of society that should get attention is the problem of typhoid fever. Typhoid fever is a disease that is prone to occur in Indonesia, because of the characteristics of the climate that is very prone to diseases related to the seasons. The occurrence of diseases related to the seasons in Indonesia can be seen increasing the incidence of environmentally based diseases in the rainy season. Diseases to watch out for during the rainy season are ISPA, leptosiposis, skin diseases, diarrhea, dengue fever and typhoid fever (Ministry of Health, 2012). The absence of a disease in an area depends on the number of people who understand the appropriate environmental conditions for the life of diseasecausing microorganisms. Agricultural areas, farms, the habit of using feces for fertilizer, environmental hygiene, poor sanitation and hygiene of individuals and poverty are factors that can increase the spread of disease. Typhoid fever is a disease that is easily contagious and can attack many people, so it can cause outbreaks. In endemic areas the main cause of transmission of typhoid fever is contaminated water while in non-endemic areas food contaminated by salmonella typhi is the most responsible for the transmission of typhoid fever (Nurvina, 2013).

According to World Health Organization (WHO) data in 2010, it estimates that there are about 17 million cases of typhoid fever worldwide with an incidence of 600,000 deaths each year. Data of Dr. Abdoer Rahem Hospital in 2013 stated that typhoid fever was included in the 3rd position of inpatient diseases in 2012. The 5-14 age group was the most affected by typhoid fever, with 136 cases out of 406 cases. Based on a report from Dr. Abdoer Rahem Situbondo Hospital in 2014 stated that the incidence of typhoid fever increased from 2011 to 2013. Typhoid fever is found in indonesian people' lives, both in urban and rural areas. Typhoid fever disease is closely related to the quality of individual hygiene (such as the habit of washing hands before eating, washing hands after defecation) and environmental sanitation (unhealthy home environment, cleanliness around the home environment is lacking) as well as the behavior of people who do not support healthy living (Kepmenkes RI No. 364, 2006).

The incidence of typhoid fever is associated with healthy clean living behaviors such as poor environmental sanitation (not using latrines when babbling, poor quality of clean water sources) poor hygiene of individuals (not washing hands before eating). From the results of previous research shows that the habit of not washing hands with soap and clean water is a relationship of typhoid fever (Whidy, 2012). Pathogenesis of typhoid fever consists mainly of 3 processes, namely the process of invasion of Salmonella typhi bacteria to the intestinal epithelial cell wall, the process of living ability in macrophages and the process of breeding germs in macrophages. Salmonella typhi bacteria enter the human body through the mouth along with contaminated food or beverages.

Recorded the number of pain caused by typhoid fever in the working area of the Jayawijaya District Health Office there are reports of weeks 1 to week 42 of 2020 there are 369 typhoid sufferers (Dinkes Jayawiya Regency, 2020) and increased where recorded rank 3 of existing disease cases.

Factors that are very closely related to the incidence of typhoid fever are unqualified environmental sanitation such as the availability of human waste disposal, the availability of waste disposal and household waste, the availability of safe food storage facilities, sanitation of clean water and poor hygiene of individuals including the habit of washing hands before meals, the habit of washing hands after defecation, low hygiene of food and beverages such as washing vegetables with contaminated water or serving unhealthy foods. Environmental sanitation and individual hygiene is one of the causes of typhoid fever incidence seen from the overall state of environmental sanitation in the Jayawijaya District Health Office which is still inadequate such as the ownership of basic sanitation facilities that include the ownership of clean water sanitation, the type of clean water facilities used by most residents.

Although patients with typhoid deman experience fluctuating, but every year the occurrence still appears. To solve this problem, there needs to be cooperation from the government and the community, because the community is a very important component in efforts to control typhoid fever. Family knowledge of typhoid fever needs to be unearthed because the family is part of the 
community. Typhoid fever can occur due to a lack of family awareness about typhoid fever. It is expected that the higher one's knowledge about typhoid fever and the dangers posed by the community participation in typhoid fever control efforts.

However, the high knowledge of people about typhoid fever is not enough if it is not accompanied by real actions in daily life. Because if the individual only knows but does not have the ability to live a healthy and clean life will be in vain. From this, it is necessary to be reviewed, if the knowledge is high whether it is always followed by good attitudes and behaviors as well.

The purpose of this study is to Analyze Factors related to the incidence of Typhoid Fever in the Working Area of the Jayawijaya District Health Office

\section{MATERIALS AND METHODS}

The research design used is quantitative analytics method using quantitative data. The type of approach used is case control. The population is 74 patients with typhoid fever. The large sample taken as many as 37 respondents, with a large comparison of samples between the number of respondents in the case group is 37 respondents, and 37 respondents as a control group, so the total number of samples is 74 respondents. Sampling techniques used in this study are simple random sampling techniques.

\section{RESULT}

\section{Univariate Analysis}

\section{Respondent Characteristics by Gender}

Table 1 Distribution of Frequency characteristics of respondents based on Gender, Age, Education, Occupation, Individual Hygiene, Knowledge, and Environmental Sanitation in The Work Area of The Health Office of Jayawijaya Regency.

\begin{tabular}{|c|c|c|c|}
\hline No. & characteristic & $\sum$ & $\%$ \\
\hline \multirow[t]{3}{*}{1} & gender & & \\
\hline & $\operatorname{man}$ & 42 & 56,8 \\
\hline & woman & 32 & 43,2 \\
\hline \multirow[t]{3}{*}{2} & age & & \\
\hline & $<30$ Years & 22 & 29,7 \\
\hline & $>30$ Years & 52 & 70,3 \\
\hline \multirow[t]{3}{*}{$\overline{3}$} & education & & \\
\hline & Elementary - Junior High School & 43 & 58,1 \\
\hline & HIGH SCHOOL - ACADEMIC & 31 & 41,9 \\
\hline \multirow[t]{7}{*}{4} & work & & \\
\hline & laborer & 11 & 14,9 \\
\hline & farmer & 35 & 47,3 \\
\hline & merchant & 3 & 4,1 \\
\hline & Private Employees & 4 & 5,4 \\
\hline & Civil Servants & 6 & 8,1 \\
\hline & Not Working & 15 & 20,3 \\
\hline \multirow[t]{3}{*}{5} & Individual Hygiene & & \\
\hline & good & 35 & 47,3 \\
\hline & Less Good & 39 & 52,7 \\
\hline \multirow[t]{3}{*}{6} & knowledge & & \\
\hline & good & 32 & 43,2 \\
\hline & Less Good & 42 & 56,8 \\
\hline \multirow[t]{4}{*}{7} & Environmental Sanitation & & \\
\hline & good & 33 & 44,6 \\
\hline & Less Good & 41 & 55,4 \\
\hline & Total & 74 & 100,0 \\
\hline
\end{tabular}


Based on table 1 Characteristics of respondents Gender can be known that the majority of respondents are male as many as 42 people $(56.8 \%)$. Based on table 4.9 above, it can be known that most of the respondents who are at risk of typhoid fever aged $>30$ years are as many as 52 people $(70.3 \%)$. While respondents who are not at risk of developing Typhoid Fever aged <30 years as many as 22 people (29.7\%), Pendidkan can be known that most of the respondents educated elementary-junior high school graduates are as many as 43 people $(58.1 \%)$. While respondents are educated in the upper secondary high school- Academic as many as 31 people (41.9\%), The work can be known that most of the respondents have a job as a farmer that is as many as 35 people $(47.3 \%)$. While the fewest respondents have a job as a trader that is as many as 3 people $(4.1 \%)$, Individual Hygiene can be known that most respondents have a poor level of individual hygiene that is as much as 39 people (52.7\%), And from knowledge can it is known that most of the respondents have a poor level of knowledge, namely as many as 42 people (56.8\%), while from Environmental Sanitation it can be known that most of the respondents have poor environmental sanitation which is as many as 41 people $(55.4 \%)$.

\section{Bivariate Analysis}

Bivariate analysis is used to determine the relationship between Age, Education,

Knowledge, Environmental Sanitation and Individual Hygiene with the incidence of Typhoid Fever in the Working Area of The Health Office of Jayawijaya Regency. Bivariate analysis in this study using chi-squaretest.

Table 2 Cross Tabulation Of The Relationship between Age, Education, Knowledge, Environmental Sanitation and Individual Hygiene with Typhoid Fever Incidence

\begin{tabular}{|c|c|c|c|c|c|c|c|}
\hline \multirow{3}{*}{ No. } & \multirow{3}{*}{ characteristic } & \multirow{2}{*}{\multicolumn{2}{|c|}{$\begin{array}{l}\text { Incidence } \\
\text { Fever } \\
\text { case }\end{array}$}} & \multicolumn{2}{|c|}{ f Typhoid } & \multirow{3}{*}{ P Value } & \multirow{3}{*}{ OR $(95 \%$ CI $)$} \\
\hline & & & & \multicolumn{2}{|c|}{ control } & & \\
\hline & & $\sum$ & $\%$ & $\sum$ & $\%$ & & \\
\hline \multirow[t]{3}{*}{1} & age & & & & & \multirow{3}{*}{0,445} & 1,685 \\
\hline & $<30$ Years & 13 & 35,1 & 9 & 24,3 & & $(0,614-4,626)$ \\
\hline & $>30$ Years & 24 & 64,9 & 28 & 75,7 & & \\
\hline \multirow[t]{4}{*}{2} & education & & & & & \multirow{4}{*}{0,000} & 10,764 \\
\hline & Graduated & 31 & 83,8 & 12 & 32,4 & & $(3,538-32,747$ \\
\hline & $\begin{array}{l}\text { elementary and junior } \\
\text { high school }\end{array}$ & & & & & & \\
\hline & $\begin{array}{l}\text { Graduated high school- } \\
\text { ACADEMIC }\end{array}$ & 6 & 16,2 & 25 & 67,6 & & \\
\hline \multirow[t]{3}{*}{3} & knowledge & & & & & \multirow{3}{*}{0,000} & \multirow{3}{*}{$\begin{array}{c}10,130 \\
(3,428-29,931)\end{array}$} \\
\hline & good & 7 & 18,9 & 26 & 70,3 & & \\
\hline & Less Good & 30 & 81,1 & 11 & 29,7 & & \\
\hline \multirow[t]{3}{*}{4} & Environmental & & & & & \multirow{3}{*}{0,001} & \multirow{3}{*}{$\begin{array}{c}5,744 \\
(2,092-15,766)\end{array}$} \\
\hline & Sanitation & & & & & & \\
\hline & $\begin{array}{l}\text { good } \\
\text { Less Good }\end{array}$ & $\begin{array}{c}9 \\
28\end{array}$ & $\begin{array}{l}24,3 \\
75,7\end{array}$ & $\begin{array}{l}24 \\
13\end{array}$ & $\begin{array}{l}64,9 \\
35,1\end{array}$ & & \\
\hline \multirow[t]{4}{*}{5} & Individual Hygiene & & & & & \multirow{4}{*}{0,000} & \multirow{4}{*}{$\begin{array}{c}13,333 \\
(4,377-40,618)\end{array}$} \\
\hline & good & 7 & 18,9 & 28 & 75,7 & & \\
\hline & Less Good & 30 & 81,1 & 9 & 24,3 & & \\
\hline & $\begin{array}{ll}\text { Total } \\
\end{array}$ & 37 & 100 & 37 & 100 & & \\
\hline
\end{tabular}

Based on table 2 Age Characteristics, it can be seen that respondents aged $>30$ years were 24 people (64.9\%) including the case group. While the respondents who had age $>30$ years were 28 people (75.7\%) including the control group and respondents aged $<30$ years were 13 people $(35.1 \%)$ in the case group while respondents aged $<30$ years were $(24,3 \%)$ in the control group. The results of the chi square test analysis of the relationship between the age of the respondent and the incidence of typhoid fever showed that the value of $p=0.445$ more than $=0.05$ was known to have an OR of 1.685 
at risk of developing typhoid fever. So it can be concluded that statistically there is no relationship between the age of the respondent and the incidence of typhoid fever. Education it can be seen that 31 respondents $(83.8 \%)$ who have an education level graduated from elementary-junior high school $(83.8 \%)$ are included in the case group. While the respondents who had an elementary-junior high school education level were 12 people (32.4\%) including the control group because the respondents who finished elementary-junior high school who did not suffer from typhoid fever were also at risk of developing typhoid fever because of low education so that knowledge was lacking. The results of the chi-square test analysis of the relationship between education and the incidence of typhoid fever showed that the value of $p=0.000$ was less than $=0.05$. So it can be concluded that statistically there is a relationship between education and the incidence of typhoid fever. OR $=10,764>1$, so statistically it can be concluded that respondents who have basic education completing elementaryjunior high school are 10.7 times at risk of developing typhoid fever compared to respondents who have higher education and upper secondary education. Knowledge can be seen that respondents who have poor knowledge as many as 30 people $(81.1 \%)$ are included in the case group. While respondents who have poor knowledge are 11 people (29.7\%) including the control group. The results of the chi-square test analysis of the relationship between respondents' knowledge and the incidence of typhoid fever showed that the value of $p=0.000$ was less than $=0.05$. So it can be concluded that statistically there is a relationship between personal hygiene and the incidence of dermatitis OR value $=10,130>1$, so statistically it can be concluded that respondents who have poor knowledge are 10.1 times at risk of typhoid fever. It can be seen that poor environmental sanitation good as many as 28 people $(75.7 \%)$ including the case group. Meanwhile, 13 people $(35.1 \%)$ had poor environmental sanitation, including the control group. The results of the chi-square test analysis of the relationship between environmental sanitation and the incidence of typhoid fever showed that the value of $p=$ 0.001 was less than $=0.05$. So it can be concluded that statistically there is a relationship between environmental sanitation and the incidence of dermatitis OR value $=5,744>1$, then statistically it can be concluded that respondents who have poor environmental sanitation are at risk of 5.7 times getting typhoid fever, and from environmental hygiene it can be seen that personal hygiene is not good as many as 30 people $(81.1 \%)$ including the case group. Meanwhile, 9 people with poor personal hygiene $(24.3 \%)$ were included in the control group. The results of the chi-square test analysis of the relationship between personal hygiene and the incidence of typhoid fever showed that the value of $\mathrm{p}=$ 0.000 was less than $=0.05$. So it can be concluded that statistically there is a relationship between personal hygiene and the incidence of typhoid fever. OR value $=13.333>1$, statistically it can be concluded that respondents who have poor personal hygiene are at risk of 13.3 times getting typhoid fever.

\section{DISCUSSION}

\section{Knowledge Relationship with Typhoid Fever}

Based on the results of the study, it is known that there is a relationship between the level of knowledge of respondents and the incidence of Typhoid Fever in the Working Area of the Jayawijaya District Health Office. Chi-square test results obtained a value of p-value $(0.000)<\alpha(0.05)$ which means there is a relationship between the level of knowledge of respondents and the incidence of typhoid fever in the Working Area of the Jayawijaya District Health Office. It can be known that the level of knowledge of respondents who are not good has a greater risk of developing typhoid fever compared to the level of knowledge of good respondents have a smaller risk of developing typhoid fever, so it can be said that the level of knowledge is one of the risk factors for the onset of typhoid fever.

Based on the results of the study as many as 30 case respondents $(81.1 \%)$ it is said to be less good because of the low knowledge of respondents so that behaviors such as maintaining food hygiene, food storage, and handwashing habits become low so as to cause typhoid fever. While the results of the study as many as 11 respondents control $(29.7 \%)$ have poor knowledge but are not at risk of developing typhoid fever. In the opinion of researchers, respondents' knowledge is less due to the low education of respondents so that knowledge about cleanliness and poor presentation of food becomes a factor that influences the incidence of typhoid fever. 


\section{Environmental Sanitation Relationship with Typhoid Fever}

Based on the results of the study, it is known that there is a relationship between environmental sanitation and the incidence of Typhoid Fever in the Working Area of the Jayawijaya District Health Office. Chi-square test results obtained p-value $(0.001)<\alpha(0.05)$ which means there is a relationship between environmental sanitation and the incidence of typhoid fever in the Working Area of the Health Office of Jayawijaya Regency. It can be known that poor environmental sanitation has a greater risk of developing typhoid fever. So it can be said that environmental sanitation is one of the risk factors for the onset of typhoid fever.

Based on the results of the study as many as 28 respondents cases $(75.7 \%)$ have poor environmental sanitation because of facilities and infrastructure such as the availability of clean water, the provision of latrines, waste disposal is not good so that the risk of developing Typhoid Fever while as many as 13 respondents control $(35.1 \%)$ have poor sanitation but are not at risk of developing typhoid fever. In the opinion of hygiene researchers it is very important for the health of both physical and nonphysical health as well as in the environment or a clean place is also part of health. Therefore, the sanitation trend concerns hygiene from the side of maintaining or maintaining with clean and simple activities that have a good impact on the community. Facilities and infrastructure also affect for a person to do environmental hygiene such as the availability of clean water, the availability of landfills and the availability of household landfills it is very necessary for the community to meet the needs of environmental sanitation.

\section{Relationship of Individual Hygiene with Typhoid Fever}

Based on the results of the study, it is known that there is a relationship between individual hygiene and the incidence of Typhoid Fever in the Working Area of the Jayawijaya District Health Office. Chi-square test results obtained p-value value $(0.000)<\alpha(0.05)$ which means there is a relationship between individual hygiene and the incidence of typhoid fever in the Working Area of the Jayawijaya District Health Office. It can be known that poor individual hygiene has a greater risk of developing typhoid fever compared to good individual hygiene has a smaller risk of developing typhoid fever, so it can be said that individual hygiene is one of the risk factors for the onset of typhoid fever.

Based on the results of the study as many as 30 case respondents $(81.1 \%)$ have poor individual hygiene such as the habit of washing hands before meals and after activities so that the risk of developing typhoid fever while as many as 9 respondents control (24.3\%) have poor individual hygiene but are not at risk of developing typhoid fever. In the opinion of researchers the act of maintaining one's hygiene and health is one of the factors that influence the incidence of typhoid fever. Because if a person is not paying attention to his hygiene then the risk of contracting Salmonella Thypi bacteria will be very easily transmitted to him so that people should often pay attention and maintain themselves such as the habit of washing hands every before or after activities.

\section{CONCLUSION}

Based on the results of the study, there is a relationship between knowledge, environmental sanitation, personal hygiene and the incidence of Typhoid Fever in the Jayawijaya District Health Office Work Area, and the results of this study are expected to increase kinship with patients as well as by providing health services to patients' home visits. Sugesstion from the study are : 1 . For Health Agencies : It is advisable for the puskesmas in the Jayawijaya District Health Office to increase kinship with patients as well as by providing health care services for patients' home visits. And besides that, health workers provide counseling about the importance of maintaining personal hygiene and the surrounding environment and to increase knowledge about the prevention of Typhoid Fever. 2. For the Community: People who live in the Jayawijaya District Health Office Work Area should pay more attention to their diet, maintain food hygiene such as paying attention to when serving and storing food, handling food and maintaining cleanliness such as washing hands before and after eating, providing trash bins for disposal of waste or garbage. for every day so as to improve personal hygiene and the surrounding environment. 3. For Further Researchers: It is hoped that research can be carried out based on other factors, different variables, larger number of samples, different places, more precise designs and still influential with the incidence of Typhoid Fever. 


\section{ACKNOWLEDGMENTS}

Researchers get a lot of guidance and encouragement from various parties. For this reason, the researcher would like to thank:

1. Prof. Dr. H. Sandu Siyoto, S.Sos., SKM., M.Kes, as Chancellor of IIK STRADA Indonesia.

2. Dr. Yuly Peristiowati, S.Kep Ns., M.Kes., as Director of Postgraduate Public Health Sciences IIK STRADA Indonesia and Advisor 1 in the preparation of Proposals and Theses.

3. Dr. Abdul Muhith, S.Kep. Ns., M.Tr. Kep., M.Kes., as Advisor 2 who has guided researchers in completing this thesis well

4. Head of Jayawijaya District Health Office, dr. Willy E. Mambieuw, Sp.B who has supported and provided recommendations in research.

5. Director of Wamena Hospital, dr. Felly G. Sahureka, Sp.PK who has given permission to researchers to conduct research.I

6. The beloved wife of dr. Viska Wahyu Arianti, the children of Admiral Wahyuari Onewa Ura and Kayana Wahyuari Onewa Ura who have given motivation and enthusiasm and helped in the completion of this thesis.

7. The researcher's beloved family as a form of respect and devotion to the researcher, as well as thanks for the prayers that are always offered and the endless encouragement and enthusiasm to achieve the success and goals of the researcher

8. Friends who have motivated and helped in the completion of this Thesis.

\section{REFERENCES}

Addin A. 2009. Pencegahan dan Penanggulangan Penyakit, Bandung: PT. Puri Delco.

Alamsyah, D. dan Ratna M. 2013. Pilar dasar Ilmu Kesehatan Masyarakat. Yogyakarta: Nuha Medika.

Alimul Hidayat, Aziz. 2012. Metode Penelitian Keperawatan dan Analisis Data.Jakarta : Salemba Medika.

Arikunto, S. 2011. Prosedur Penelitian Suatu Pendekatan Praktek. Jakarta: Rineka Cipta.

Atikah Proverawati dan Eni Rahmawati. 2012. Perilaku Hidup Bersih \& Sehat (PHBS), Yogyakarta: Nuha Medika.

Departemen Kesehatan Republik Indonesia, 2006, Pedoman Pengendalian Demam Tifoid, Jakarta: Direktorat Jendral PP \& PL

Keputusan Menteri Kesehatan Republik Indonesia Nomor 364/MENKES/SK/V/2006 Tanggal 19 Mei 2006 Tentang Pedoman Pengendalian Demam Tifoid.

Keputusan Menteri Kesehatan Republik Indonesia Nomor. 829/MENKES/SK/VII/1999 Tentang Persyaratan Kesehatan Perumahan.

Muthia, dkk. 2010. Beberapa Faktor yang Mempengaruhi Kekurangan Cairan Elektrolit Pada Penderita Demam Typhoid di Perawatan Interna RSUD Labuang Baji Makassar. Jurnal Ilmiah Kesehatan Diagnosis Volume 4, Nomor 4, Tahun 2014.

Notoatmodjo, Soekdjo 2010. Metodologi Penelitian Kesehatan. Jakarta: Rineka Cipta.

Notoatmodjo, Soekdjo 2011. Kesehatan Masyarakat: Ilmu \& Seni. Jakarta: Rineka Cipta.

Notoatmodjo, Soekdjo 2012. Metodologi Penelitian Kesehatan.Jakarta: Rineka Cipta

Muhith A., 2011. Konsep dan Penerapan Metodologi Penelitian kesehatan Yogyakarta: Nuha Medika.

Nurvina WA. 2013. Hubungan antara Sanitasi Lingkungan Higiene perorangan dan Karakteristik Individu dengan Kejadian Demam Tifoid di Wilayah Kerja Puskesmas Kedungmundu Kota Semarang. Skripsi. Universitas Negeri Semarang, Semarang.

Peraturan Menteri Kesehatan Republik Indonesia Nomor. 1077/MENKES/PER/V/2011 Tentang Pedoman Penyehatan Udara Dalam Ruang Rumah.

Peraturan Menteri Kesehatan Republik Indonesia Nomor. 3 tahun 2014 Tentang Sanitasi Total Berbasis Masyarakat.

Peraturan Menteri Kesehatan Republik Indonesia Nomor. 32 tahun 2017 Tentang Standar Baku Mutu Kesehatan Lingkungan Dan Persyaratan Kesehatan Air Untuk Keperluan Higiene Sanitasi, Kolam Renang, Solus Per Aqua, Dan Pemandian Umum

Riskesdas. (2007). Riset Kesehatan Dasar_Laporan Kesehatan 2007. Jakarta: Badan Penelitian dan Pengembangan Kesehatan Departemen Kesehatan Republik Indonesia. 
Rudi Haryono. 2012. Keperawatan Publishing.

Supriyono. 2011. Demam
Medikal Bedah Sistem Pencernaan. Yogyakarta: Gosyen http://gizi.depkes.go.id/wp content/uploads/2012/08/DEMAM-TIFOID- 2011.pdf pada tanggal 24 Maret 2018.

Suyono, A. (2006). Hubungan Sanitasi Lingkungan dan Higiene Perorangan dengan Kejadian Demam Tifoid di Puskesmas Bobotsari Kabupaten Purbalingga.Tahun 2015. Jurnal. Universitas Diponegoro, Semarang.

Swarjana, I Ketut. 2015. Metodologi Penelitian Kesehatan. Yogyakarta: Hak Cipta.

T.H Rampengan. 2007. Penyakit Infeksi Tropik pada Anak. Jakarta: EGC. Tarwoto dan Wartonah. 2006. Kebutuhan Dasar Manusia dan Proses Keperawatan, Jakarta: Salemba Medika.

Wahyu, RU. 2015. Menjadi dokter bagi anak anda. Yogyakarta: Cakrawala Ilmu. Whidy, Y. 2012. Diagnosis Dan Penatalaksanaan Demam Tifoid. Jakarta: EGC. Widoyono. 2011. Penyakit Tropis. Jakarta: Erlangga. 